\title{
Effects of Leadership Style on Employee Performance of Fast Moving Consumer Goods (FMCGS) in South Africa
}

\author{
Solomon OMONONA, Olabanji ONI, Joseph OBAMEN \\ University of Fort Hare, Department of Management, Alice, South Africa \\ omononamise@gmail.com, ooni@ufh.ac.za, obamenjoseph@gmail.com
}

\begin{abstract}
The study seeks to assess the effects of leadership style on Employee performance (EP) of fast moving consumer goods (FMCGs) companies in South Africa. The specific objectives are: to determine the effects of autocratic leadership style on EP; to evaluate the effect of participative/ democratic leadership style on EP; to ascertain the relationship between laissez faire leadership style and EP; to assess the relationship between transactional leadership style and EP in the FMCGs. Quantitative research survey design was adopted for the study; both primary and secondary sources of data were utilized during the investigation. The sample size of 233 was obtained from the estimated population using Rao soft online calculator at $5 \%$ error tolerance and 95\% level of confidence. Data was collected via questionnaires and analyzed utilizing Simple Linear Regression (SLR) and Pearson product moment correlation (PPMC). It was discovered that there is a significant relationship between the various leadership styles and the performance of organisations. However, transactional leadership style was found to account for more influence on employee performance than other styles of leadership. Therefore, the study recommends the transactional style of leadership for managers of FMCGs in order to increase employee performance, ensure profitability and sustainability of the organisation.
\end{abstract}

Keywords: Autocratic leadership (AL); participative/ democratic leadership (PDL); laissez-faire leadership (LFL); Transactional leadership (TL) and Employee Performance (EP).

\section{Introduction}

The need for effective and efficient leadership skills in organizations today is no doubt one of the key areas in human resource-related outcomes, especially in a fast-changing and increasingly competitive global market environment. Leadership style in recent times has become one of the most well-thought-out topics in management. This is undoubtedly so because it is one of the most important areas or aspects that is sometimes very prickly in organizational research (Puni et al., 2014). Inyang (2004); Ukaidi (2016) posits that the term "leadership" involves a process or act that is devoid of the use of force or intimidation to obtain compliance from a subordinate in an organization. Leadership plays an important role during group-group, individual-individual and individual-group interactions or any form of communication within the organization, as such the aptitude of management to achieve "collaborated effort" hinge on leadership competency (Obiwuru et al., 2011). In addition, Fry, (2003) in Obiwuru et al. (2011) x-rayed leadership as a well-planned procedure of giving inspiration/motivation to enrich workers' potential for development and growth by the leader. While Northouse (2004) opines that leadership has to do with individual influencing a group of people to accomplish a pre-determined objective(s). These objectives or tasks can be achieved using the appropriate leadership style in the right situation.

Who is a leader? A leader is like an instructor or guide who goes the extra mile to inspire and encourage his subordinate in order to achieve the desired corporate goals, being a leader encompasses being skilled in inspiring and motivating workers through the use of authority, but by the mere implementation of control (legal authority), that is different from manipulating. In addition, it involves making people or employees perform their duties and still have their dignity and free consent (Acuña, 2017). The act of leadership can be traced centuries back to the Biblical figures, the Greek champions and Egyptian monarchs, who had one thing or the other in common- "leadership". Every leader has its unique way or style of achieving the result through the collaborated effort of the followers. Leadership style is a way of using the influence of a leader as a tool to inspire employee in any organization; it is also known as a leader's method of providing direction, affecting plans, and motivating individuals to achieve a set objective. In the field of management, there are four popular styles of leading followers; Autocratic, democratic, laissez-faire and transformational leadership styles. 
The performance of the employee in every organization largely depends on the leadership styles adopted by its management team it is noteworthy to understand that a highly satisfied proportion of employees is directly related to the organizational performance. In addition, a satisfied employee will be loyal, committed and emotionally attached to the organization. In the context of leadership, employee satisfaction can be said to be the velocity of happiness of workers, which determines their efficacy in discharging their tasks in the workplace as set by the employer. Therefore, the satisfaction of employee and proper coordination of other organizational resources is expected to lead to high employee performances. Investigating the leadership styles on employee performance is key to national development because the fast moving consumer goods sector is one of the most important economy driving forces in South Africa. According to PWC, (2012) the FMCG sector is already a juggernaut in South Africa compared to other countries in Africa. As of 2011, retail sales increased to a trillion rands for the first time in history; however by 2016, it had grown to R1.46 trillion. Many big holdings dominated this industry. These companies own most of the biggest brands some of which include: Shoprite, Pick 'n Pay, Spar, Woolworths and Massmart etc. They all make up $80 \%$ of the local retail sales with a series of sub-brands aiming at meeting the needs of various consumer market segments.

However, the industry over time has been affected with various challenges ranging from changes in the technological landscape, cultural diversity, globalisation and implementation of black economic empowerment programme which pose challenges to the organisations and their operators in South Africa (Eustace, 2013). These challenges sometimes result to high employee turnover and low productivity, according to Annual South African Human Resource Recruitment Trends Report (2015), most of the FMCGs companies are reporting staff turnover of between 5-10\% yearly. In 2014, these companies managed to fill the majority of their vacant positions, although a few did have vacant positions that were carried over to 2015. Many organizations in the industry are faced with dwindling productivity and difficulties in retaining employees since the leadership of such organizations are unable to identify the factors which satisfy their employees and the resultant loyalty. However, employee turnover statistics are being used by organizations as a parameter to measure the effectiveness of the leadership style used, and the impact of turnover on its operations because employee satisfaction is inversely proportional to its turnover.

Top-level employees, particularly those with uncommon expertise, are regularly being offered mouthwatering jobs universally and some of these offers are too striking for them to turn down especially when not satisfied with the present job (Cappelli, 2000). Employees rarely quit their job on the spot. They become discontented and stay unfastened for relatively a while before leaving. In view of leadership challenges faced by the sector, it becomes worrisome to empirically address or investigate the effects of leadership styles on the performance of the employee in the FMCGs. The study seeks to assess the effects of leadership style on the Employee performance (EP) of fast moving consumer goods (FMCGs) companies in South Africa. The specific objectives are: to determine the effects of autocratic leadership style on EP; to evaluate the effect of participative/ democratic leadership style on EP; to ascertain the relationship between laissez-faire leadership style and EP; to assess the relationship between transactional leadership style and EP in the FMCGs. The remaining part of this paper discusses the literature review, methodology, findings and the conclusion and recommendations.

\section{Literature Review}

The Definition of Leadership Style and Leadership: The lexicon "Leadership style" is practically the same as the leader's conduct. It is the manner by which the leader influences the followers. In Some 2,500 years ago, as posits by Khan, Khan, Qureshi Ismail, Rauf, Latif \& Tachir (2015), Socrates contended that leadership is all the time situational: technical and professional abilities of a leader are particular to situations and are not transferable. But he also explained that a good business leader is synonymous to that of an Army Commander because they both share similarities in planning, organizing, coordinating and controlling of subordinates. Leadership style takes care of upward vertical communication and also endeavors to encourage social interactions in the organization. It is the medium in which the line manager comes in contact with the workers etc. Puni, Ofei1 \& Okoe, (2014) were of the opinion that humankind has been using organizations to achieve its stated objectives for over two centuries now. 
Despite the impact of leadership on the organizational performance, it was not until the 1900s that formal research into leadership began. Because of the cohort of interest in the subject matter, the discipline has been developing fast with more than three hundred and fifty definitions on the concept (Hamidifar, 2009). Different authors and scholars have varying definitions and meanings for leadership, but all are pointing to one thing which is the attitude or behavior of the leader to his subordinates in order to achieve the set objectives. The leadership style crusade came in full swing at the Ohio State University among Scholars in 1945. This research (leadership style) has gained popularity considering the need for leaders who will exhibit the appropriate style toward organizational success (Puni et al., 2014). Subsequently, the works of earlier contributors to this field were expanded in 1947 at the University of Michigan by Likert, Kahn, Maccoby and Katz by mainly examining the correlation between Leadership/supervisor behavior and employee satisfaction and productivity. The research documented two styles of leadership: (1) Production Centered (PC) and (2) Employee Centered (EC) leadership. EC leadership emphasizes employee welfare and satisfaction rather than its productivity while the Production Centered (PC) leadership lays more emphasis on the output of workers and gives less attention to employee welfare and planning. They, however, concluded that there are several patterns or styles of leadership, but every leader has his own peculiar pattern or style of leading, other styles include; Autocratic, Democratic/Participative, Laissez Faire and Team leadership style.

\section{Types of Leadership}

A. Autocratic Style: This type of leadership style gives more prominence to productivity/performance rather than employee welfare. The leader is considered to be all-knowing. Input from the subordinates is jettisoned while employee innovative skills are suppressed. This situation is described by Khan et al. (2015) as the autocrat setting the rules for his team or group and expects strict adherence without suggestion from his teammates or subordinates. In the words of McGregor (1960), the autocratic leader is synonymous to a theory X manager because both leaders exhibit the same qualities. An autocratically-led organization will result in the invitation of potential cruelty or manipulation by excessively dominant personalities, suppress worker or subordinate and destroys teamwork and creativity. In addition, contemporary worker or employee may not respond positively to the dictatorial style, which can destruct the communication flow in the organization. However, autocratic leadership is appropriate for circumstances where there is a limited time frame for the team to brainstorm on issues or when the most experienced member of the team happens to be the leader. For example, Gill (2014) opines that automatic style is common in the aviation sector, because it ensures error-free procedures which lead to safety and affordability in aerospace production, bearing in mind the lots of cargo, commercial and NASA flights that lift-off and arrive safely consistently, accolades ought to be given to the aviation sector for steady travellers' safety. The autocratic style adopted by the Aviation team contributed immensely to their success. No doubt an Autocrat achieves result or goal through people.

B. Democratic/Participative Style: This style is grounded on mutual respect and has been in focus in recent decades. It was between the periods of the 1930s to '40s that the notable Scholar Kurt Lewin led the research that helped discover the significance in this leadership style (Gill, 2014). The democratic style most times is linked with participatory style because it involves alliance or teamwork between the leader and follower. In other words, it entails empowering teammate or workers to become active in the decision-making process of the organization, keeping staff in the loop about everything that affects their work and sharing decision making and problem-solving responsibilities. Also, this leadership pattern allows workers or subordinates to be creative, get promoted and celebrate achievement for it employee. There are lots of corporation that have used and still using this style today, notable among them are; Google, Genentech and Amazon.com. Over time, research has shown that democratic/participative leadership has proven to be the most effective and the best form of leadership in some situations. This type of Leadership style will not only increase the productivity of the organization but also increase the employee sense of belonging that leads to organizational citizenship. A democratic leader achieves goals with the people.

C. Laissez-faire Style: This type of leaders considered as uninvolved in the decision making process with their followers and members. In fact, laissez-faire leadership is an absence of leadership style. This style of leadership gives the subordinates the latitude to make or take a decision on their own. This is common among organizations like the advertising companies, start-up social media companies, venture capital investment 
companies, product design firms, high-end architectural and specialized engineering firms and research and development departments etc. According to Gill (2016), laissez-faire is one of the three basic management styles and is the direct opposite of autocratic rule. In other words, it can be said to be inversely related to the autocratic rule. Robbins et al. (2007) in Chaudhry \& Javed (2012) and Luthans, (2005) explained the laissezfaire style as the leadership that "Abdicates responsibilities and avoids making decisions". The laissez-faire style always does not interfere with the decision power of the subordinates. The freedom to take a decision and be accountable for such action is vested on the subordinates (Chaudhry, 2012).

D. Transactional Leadership: This leadership style is based on "reward", that is, followers get rewarded with praise, recognition etc. for an excellent performance but get reprimanded for a negative act. This system of leadership promotes both rewards and punishments as a means of ensuring compliance from its workers. This type of leader, according to Odumeru \& Ifeanyi, (2013) does not think outside the box; rather, he works within the existing structure and system. He tends to negotiate his way to achieving organizational objectives. They are "leaders who lead principally by using social exchanges for transactions" (Robbins et al., 2007). Transactional leaders are also concerned with the contingent, the positive and negative reinforcement for reward and punishments respectively. For negative contingent, a transactional leader can be active or passive (management -by- exemption). Transactional leaders stabilize the organization by recognizing followers' needs and desires and working out ways to satisfy them in order to optimize the workers' efficiencies. This satisfaction of needs increases employees' productivity and optimism (Daft, 2015). Transactional leadership concerns itself with granting, rather than wielding of power.

\section{Empirical Review}

Autocratic Leadership Style and Organizational Performance: Akor, (2013) studied the performance of library employee and autocratic leadership style in the Benue state of Nigeria. Data for the study was collected and analyzed through a mean and standard deviation analysis, which discovered that the job performance of academic librarians was not significantly influenced by the autocratic style of leadership. Also, Iqbal et al. (2015) investigated leadership and its effects on workers' performance using the descriptive approach and qualitative approach. Based on the research, it was discovered that an autocrat leader is only useful for short term purposes and not appropriate for a long time horizon. The tasks of this type of leader consist of trusting their subordinates to make suitable decisions and fetching vastly skilled, dependable and consistent subordinate into the organization. Therefore, this study hypothesizes that: H1: Autocratic leadership style has a significant effect on EP in the organizations under review.

Participative/Democratic Leadership Style and Organizational Performance: Chris et al. (2016) studied the influence of leadership strategies on the performance of some selected organizations in Nigeria. Under the investigation 84 usable responses obtained. The study reveals that the democratic style has a positive relationship with organizational performance. In addition, Malik et al. (2016) researched the connection between leadership styles and firm citizenship conduct in telecom organizations working in Pakistan. 144 subordinates and 72 leaders constitute the population of study from which data were collected. Data were analyzed using ANOVA to test the hypotheses formulated. However, the finding shows a positive relationship between organizational citizenship behavior and leadership styles. This study hypothesizes that: H2: Participative/democratic leadership style has a great effect on employee performance in the organizations under review

Laissez Faire Leadership Style and Organizational Performance: Chaudhry, (2012) investigated the connection between laissez-faire, transactional style and motivation. The study uses descriptive research with a population of 287. Data collected were analyzed through SPSS. It was discovered that the connection between Laissez-faire and motivation of worker is very low due to the management non-interference. The paper, therefore, concludes that laissez-faire strategy isn't a critical strategy that lifts the inspiration level of workers in comparison with other leadership strategies. Similarly, Malik et al. (2016)'s work centred on the relationship that exists between organizational citizenship behavior and leadership styles. The sample size was drawn from a pool of leaders and subordinates in the telecom companies in Pakistan. PPMC was used to analyze the data obtained. The findings affirmed that the weak relationship between organizational citizenship behavior and laissez-faire leadership style. This study hypothesizes that: $\mathrm{H}_{3}$ : There is a 
relationship between laissez-faire leadership style and employees' performance in the organizations under review.

Transactional Leadership Style and Organizational Performance: Ojokuku et al. (2012) examined the nexus between the various leadership styles and the performance of firms. Data obtained was analyzed using PPMC to test for the relationship between the variables. The findings revealed that transactional leadership has a negative effect on the performance of the organizations reviewed. The study states further that this style leads to high intention turnover and demoralizes workers. In addition, Shah and Hamid (2015) investigated the connection between transactional leadership and the performance of worker in six different banks of Pakistan. Primary data was obtained from the functional managers of the banks, which was analysed via smart-PLS. Shah and Hamid discovered that there exists a connection between transaction leadership pattern and performance. While Igbaekemen, (2014) investigated how agencies, countries, industries and organizations will achieve their set objective through a vibrant leadership strategy. This investigation is based on secondary data which submits that there is a connection between the various styles and the performance of organizations. This study hypothesizes that: $\mathbf{H}_{\mathbf{4}}$ : There is a significant relationship between transactional leadership style and employees' performance in the organizations under review.

Theoretical Review: This study is theoretically supported by the Theory X and Theory Y. It was propounded by McGregor Douglas in 1966. This theory categorizes belief or attitude system, which describes leadership performance and behaviour based upon the leader's attitude toward his subordinates. Leaders who believe in theory $\mathrm{X}$ attitude assume workers or his subordinate dislike work, therefore must be micro-managed for optimal output while leaders with the belief system of theory Y, assumes that employee or workers naturally like to perform its duties. Therefore there is no need for close supervision. Leaders with Theory Y belief system, which is associated with participative leadership style, tend to have an optimistic view of employees, who are always ready to work based on rewards and internal motivation (Tietjen and Myers, 1998). Most recent managers tend to focus more on leadership styles theory Y rather than the assumption that workers are naturally lazy and unwilling to work except under strict supervision (Theory X). Therefore, management of FMCG in South Africa must be willing to use an appropriate leadership style or theory in order to ensure profitability and sustainability.

\section{Methodology}

This research follows a survey design. Because of opinions of respondent was gathered through the administration of Questionnaire. Two hundred and thirty-three (233) sample size was utilized for the study from the selected FMCGs; this was determined via Rao soft online calculator at 95\% level of confidence and $5 \%$ margin error. The data obtained was analysed utilizing Statistical Package for Social Sciences, specifically, SLR and PPMC to determine the significance of variables, degree or strength of the relationship between variables.

\section{Analysis and Findings}

Hypothesis One: $\mathbf{H}_{\mathbf{o}}$ : Autocratic leadership style has no significant effect on EP in the organizations under review. $\mathbf{H}_{1}$ : Autocratic leadership style has a significant effect on EP in the organizations under review. To test this hypothesis, a SLR analysis method was used. It was assumed that the autocratic leadership style would have significant impact on EP in the organizations under review.

Table 1: Summaryb

\begin{tabular}{llllll}
\hline Model & R & R Square & Adjusted R Square & $\begin{array}{l}\text { Std. Error of } \\
\text { Estimate }\end{array}$ & theDurbin-Watson \\
\hline 1 & $.674^{\mathrm{a}}$ & .455 & .442 & .79769 & .379 \\
\hline
\end{tabular}

a. Predictors: (Constant) Autocratic style

b. Dependent Variable: EP 
Table 2: ANOVAa

\begin{tabular}{llllll}
\hline & Sum of Squares & DF & Square & F & Sig. \\
\hline Regression & 22.275 & 1 & 22.275 & 35.007 & $.000^{\mathrm{b}}$ \\
Residual & 26.725 & 42 & .636 & & \\
Total & 49.000 & 43 & & & \\
\hline
\end{tabular}

a. Dependent Variable: Employees performance

b. Predictors: (Constant), Autocratic style

\section{Table 3: Coefficients ${ }^{\mathrm{a}}$}

\begin{tabular}{|c|c|c|c|c|c|c|}
\hline & & Unstan & ed Coefficie & $\begin{array}{l}\text { Standardized } \\
\text { Coefficients }\end{array}$ & $t$ & Sig. \\
\hline & $\begin{array}{l}\text { (Constant) } \\
\text { Autocratic Leadership style }\end{array}$ & $\begin{array}{l}\mathrm{B} \\
-8.650 \\
2.475\end{array}$ & $\begin{array}{l}\text { Std. Error } \\
2.057 \\
.418\end{array}$ & $\begin{array}{l}\text { Beta } \\
.674\end{array}$ & $\begin{array}{l}-4.205 \\
5.917\end{array}$ & $\begin{array}{l}.000 \\
.000\end{array}$ \\
\hline$\overline{\mathrm{R}}$ & $=.674$ & & & & & \\
\hline $\mathrm{R}^{2}$ & $=.455$ & & & & & \\
\hline $\mathrm{F}$ & $=35.007$ & & & & & \\
\hline $\mathrm{T}$ & $\begin{aligned}= & 5.917 \\
& -379\end{aligned}$ & & & & & \\
\hline
\end{tabular}

Sum of squares due to regression (SSR) $=22.275$

Residual sum of squares (RSS) $=26.725$

Std. Error of the Estimate $($ SEE) $=.79769$

Interpretation: The SSR (22.275) is less than the RSS (26.725), which shows that more of the disparity in the dependent variable is elucidated. Variable R shows the degree of relationship between independent variable autocratic leadership style and dependent variable employees' performance. 0.674 , which is the coefficient correlation value represents a strong positive connection between autocratic style and the performance of the employee. The EP variation is indicated by the value of $\mathrm{R}^{2}$ which is $45.5 \%$ (coefficient of determination). Also, there is a low error of estimation with a value of 0.798 while Durbin Watson statistic is 379 (autocorrelation). Autocratic leadership style of 0.445 indicates a weak on employees' performance, which is significant statistically (with the value of $t=7.920$ ).

Hypothesis Two: $H_{0}$ : Participative/democratic leadership style has no effect on employee performance in the organizations under review. $\mathbf{H}_{2}$ : Participative/democratic leadership style has a great effect on employee performance in the organizations under review. To test this hypothesis, a SLR analysis method was used. It was assumed that Participative/democratic style has a great effect on employee performance.

Table 4: Summaryb

\begin{tabular}{|c|c|c|c|}
\hline $\mathbf{R}$ & R Square & Adjusted R Square & $\begin{array}{l}\text { Std. Error of theDurbin-Watson } \\
\text { Estimate }\end{array}$ \\
\hline $.665^{\mathrm{a}}$ & .442 & .429 & .95565 \\
\hline
\end{tabular}

a. Predictors: Participative/democratic style

b. Dependent Variable: EP

Table 5: ANOVA ${ }^{\mathrm{a}}$

\begin{tabular}{lllllll}
\hline & Sum of Squares & DF & $(\overline{\mathbf{X}})$ Square & F & Sig. \\
\hline \multirow{3}{*}{1} & Regression & 30.438 & 1 & 30.438 & 33.329 & $.000^{\mathrm{b}}$ \\
& Residual & 38.357 & 42 & .913 & & \\
\hline & Total & 68.795 & 43 & & & \\
\hline
\end{tabular}

a. Dependent Variable: Employees performance

b. Predictors: (Constant), Participative/democratic style 
Table 6: Coefficients ${ }^{\mathrm{a}}$

\begin{tabular}{|c|c|c|c|c|c|c|}
\hline & \multicolumn{2}{|c|}{ Unstandardized Coefficients } & \multirow{2}{*}{$\begin{array}{l}\begin{array}{l}\text { Standardized } \\
\text { Coefficients }\end{array} \\
\text { Beta }\end{array}$} & $\mathbf{T}$ & Sig. \\
\hline & & $\begin{array}{l}\text { B } \\
-4.429\end{array}$ & $\begin{array}{l}\text { Std. Error } \\
1.455\end{array}$ & & -3.043 & .004 \\
\hline 1 & $\begin{array}{l}\text { Participative/democratic } \\
\text { leadership style }\end{array}$ & $c_{1.786}$ & .309 & .665 & 5.773 & .000 \\
\hline
\end{tabular}

a. Dependent Variable: employees' performance

$$
\begin{array}{ll}
\mathrm{R} & =.665 \\
\mathrm{R}^{2} & =.442 \\
\mathrm{~F} & =33.329 \\
\mathrm{~T} & =5.773 \\
\mathrm{DW} & =.843 \\
\mathrm{SSR} & =30.438 \\
\mathrm{RSS} & =38.357 \\
\mathrm{SEE} & =.95565
\end{array}
$$

Interpretation: The SSR (30.438) is less than the RSS (38.357), which shows that more of the disparity in the dependent variable is elucidated. Variable $\mathrm{R}$ shows the degree of relationship between independent variable Participative/democratic leadership style and dependent variable employees' performance. 0.665 , which is the coefficient correlation value represents a strong positive connection between Participative/democratic leadership style and employees' performance. The EP variation is specified by the value of $\mathrm{R}^{2}$ which is $42 \%$ (coefficient of determination). Also, there is a low error of estimation with a value of 0.798 while Durbin Watson statistic is 843 (autocorrelation). Participative/democratic style of 0.442 indicates a weak impact between Participative/democratic leadership style and employees' performance, which is significant statistically $(\mathrm{t}=5.773)$. Therefore, the alternative hypothesis should be accepted, which means that the Participative/democratic leadership style has a strong effect on employees' performance.

Hypothesis Three: $\mathbf{H}_{0}$ : There is no relationship between laissez-faire leadership style and employees' performance in the organizations under review. $\mathbf{H}_{3}$ : There is a relationship between laissez-faire leadership style and employees' performance in the organizations under review.

Table 7: Descriptive Statistics

\begin{tabular}{llll}
\hline & $\overline{\mathbf{X}}$ & Std. Deviation & $\mathbf{N}$ \\
\hline laissez-faire leadership style & 4.0530 & 1.29776 & 233 \\
EP & 4.1818 & 1.12628 & 223 \\
\hline
\end{tabular}

\begin{tabular}{|c|c|c|c|}
\hline & & $\begin{array}{l}\text { laissez-faire } \\
\text { leadership style }\end{array}$ & employee growth \\
\hline \multirow{3}{*}{$\begin{array}{l}\text { laissez-faire } \\
\text { style }\end{array}$} & $\begin{array}{l}\text { Pearson Correlation } \\
\text { leadership } \\
\text { Sig. (2-tailed) }\end{array}$ & 1 & $\begin{array}{l}.036 \\
.818\end{array}$ \\
\hline & $\mathrm{N}$ & 233 & 223 \\
\hline & Pearson Correlation & .036 & 1 \\
\hline \multirow[t]{2}{*}{ EP } & Sig. (2-tailed) & .818 & \\
\hline & $\mathrm{N}$ & 223 & 223 \\
\hline
\end{tabular}

Table: 7 shows the statistics of the connection flanked by laissez-faire style and employees' performance, with feedback $\overline{\mathbf{X}}$ of 4.1 and std. deviation of 1.3 for employees' performance, and feedback $\overline{\mathbf{X}}$ of 4.2 and std. deviation of 1.2 for laissez-faire leadership style. By careful observation of standard deviation values 1.3 and 1.2 , it can be deduced, that independent and dependent variables have nearly the same variability of data points. This indicates that laissez-faire leadership style represents a larger fraction of variables that positively affect employees' performance.

Table 8: Correlations 
Table 8 shows the PPMC of the connection between laissez-faire style and employees' performance; the table presents significant values and correlation coefficients. The correlation value of 0.818 indicates a significant connection between laissez-faire and the performance of employees $(r=.818)$. The table value of $r=.195$ is smaller than the calculated value of correlations coefficient with 221 degrees of freedom (DF. = n-2) at alpha level for a two-tailed test $(\mathrm{r}=.818, .036<0.05)$. Meanwhile, the calculated $\mathrm{r}=.818$, is greater than the table value of .195, the null hypothesis is rejected and it is concluded that there is a significant statistical connection between laissez-faire and employees' performance as described in the probability value of ( $\mathrm{r}$ $=.818, .036<0.05)$.

Hypothesis Four: Ho: There is no significant relationship between transactional leadership style and employees' performance in the organizations under review. $\mathbf{H}_{4}$ : There is a significant relationship between transactional leadership style and employees' performance in the organizations under review. To test this hypothesis, PPMC method was used. It was assumed that there is a significant correlation between transactional leadership style and the performance of employees in the organizations under review.

Table 9: Descriptive Statistics

\begin{tabular}{llll}
\hline & $\overline{\mathbf{X}}$ & Std. Deviation & $\mathbf{N}$ \\
\hline transactional leadership style & 3.7879 & 1.25419 & 233 \\
EP & 3.0000 & 1.64246 & 233 \\
\hline
\end{tabular}

Table 9 shows the connection flanked by transactional leadership and employees' performance, with a feedback $\overline{\mathbf{X}}$ of 3.8 and std. deviation of 1.3 for employees' performance and feedback mean of 3.0 and std. deviation of 1.6 for the transactional leadership style. Via observation standard deviation values 1.3 and 1.6, it can be deduced, that independent and dependent variables have nearly the same variability of data points. This indicates that leadership style constitutes a less percentage of proxies that positively affect employees' performance

Table 10: Correlations

\begin{tabular}{llll}
\hline & & $\begin{array}{l}\text { Transactional } \\
\text { leadership style }\end{array}$ & EP \\
\hline \multirow{2}{*}{ transactional leadership style } & Pearson Correlation & 1 & .000 \\
& Sig. (2-tailed) & & 1.000 \\
& $\mathrm{~N}$ & 223 & 223 \\
EP & Pearson Correlation & .000 & 1 \\
& Sig. (2-tailed) & 1.000 & \\
& $\mathrm{~N}$ & 223 & 223 \\
\hline
\end{tabular}

Table 10 shows the PPMC of the correlation of employees' performance and transactional style of leadership; the table presents significant values and correlation coefficients. The correlation value of 1 indicates a significant connection between transactional leadership style and the performance of employees $(r=1)$. However, the calculated correlations coefficient is higher than the table value of $r=.195$ with 221 degrees of freedom (DF. $=\mathrm{n}-2)$ at alpha level for a two-tailed test $(\mathrm{r}=1, .000<0.05)$. Since the computed $\mathrm{r}=1$ is higher than the table value of .195, the null hypothesis is rejected, and it is concluded that there is a strong connection between transactional leadership and employees' performance as stated in the probability value of $(r=1, .000<0.05)$.

Discussion of the Findings: Hypothesis one was tested with SLR to determine how autocratic leadership style significantly affects the performance of employees in the fast moving consumer goods sector for the organizations under review. However, the result shows that autocratic leadership style significantly affects the EP in the FMCG organizations under review $(r=.674 ; \mathrm{F}=35.007 ; \mathrm{t}=5.917 ; \mathrm{p}<0.05)$. This finding aligns with Iqbal et al. (2015) that autocratic leadership style plays a pivot role to short term situation especially with inexperience or new employee who lacks the technical know-how about the task. In addition, such a leadership style is appropriate if the employees are constantly misusing their authority or constantly violating the company rules. Also, hypothesis two was tested using SLR analysis to ascertain how participative/democratic leadership style affects the performance of employees in the FMCGs organizations 
under review. Therefore, the alternative hypothesis, which states that the autocratic leadership style has a significant effect on employees' performance, should be accepted. The result states that participative/ democratic leadership style has a great effect $(r=.665 ; \mathrm{F}=33.329 ; \mathrm{t}=5.773 ; \mathrm{p}<0.05)$ on the performance of the organizations under review.

This outcome was supported by the work of Chris et al. (2016), which projects that democratic leadership style contributes significantly to the performance of the organisation than the laissez-faire and autocratic leadership style. He further states that the participative or democratic style achieves its objective through the sharing of decision-making process with its group member. The third hypothesis was tested utilising the Product Pearson moment statistical package to define the connection between laissez-faire leadership style and employees' performance in the organizations under review. The result shows that there exists a relationship or correlation $(\mathrm{r}=.818$; $\mathrm{P}<.05)$ between the laissez-faire leadership style and the performance of employees. In the selected fast moving consumer goods organizations, the study is in tandem with that of Chaudhry, (2012) which postulates that laissez-faire also has a positive relationship with the performance of employees but due to the pettiness of relation, it shows that other leadership strategies increase employee motivation level except for laissez-faire style.

Finally, the last hypothesis was tested using the Pearson Product moment to determine the relationship that exists between the transactional leadership style and performance of employees in the fast moving consumer good's organizations. The result shows that there exists a relationship $(\mathrm{r}=1.00 ; \mathrm{P}<.05)$ between transactional leadership style and employees' performance in the organizations under review. This is in line with the study of Saasongu (2015), which states that transactional style has a positive and substantial effect on employees' performance because contingent incentive and management by exception skills exhibited by the transactional leader has a significant positive effect on employees' performance.

\section{Conclusion and Recommendations}

In a nutshell, this research has evaluated the effects of leadership styles on organisational performance in some, selected fast moving consumer goods companies in South Africa. The analysis has shown that no doubt, there exists a significant connection between the various leadership styles and performance of organisations. Especially, transactional leadership style over time has proven to be the most productive leadership style in managing the employees of fast moving consumer's goods companies. Based on the hypotheses tests, positively significant and strongly relationships were discovered between transactional leadership style and business performance. Therefore, in order to maximize and sustain high productivity among employees of the fast moving consumer's good companies, employers or managers are encouraged to adopt the transactional style of leadership in managing the employees.

\section{References}

Acuña, B. P. (2017). Critical Revision of Leadership Styles in Management and Company Cases: Intech science. Akor, P. U. (2013). Influence of Autocratic Leadership Style on the Job Performance of Arabian Journal of Business.

Cappelli, P. (2000). A market-driven approach to retaining talent. Harvard Business Review, 78(1).

Chaudhry, A. Q. \& Javed, H. (2012). Impact of Transactional and Laissez-Faire Leadership Style on Motivation. International Journal of Business and Social Science, 3(7).

Chris, U. \& Ukaidi, A. (2016). The Influence of Leadership Styles on Organizational Performance in Nigeria. Global Journal of Human Resource Management, 4(4), 25-34.

Daft, R. L. (2015). Management, 12th ed. Cincinnati: Cengage.

Eric Gill. (2014). What is Autocratic Leadership? How Procedures Can Improve Efficiency: St. Thomas University 16401 NW 37th Avenue Miami Gardens, Florida 33054

Eustace, A. (2013). The Relationship between Leadership and Organisational Climate: Employees at an FMCG Organisation in South Africa. A thesis submitted in partial fulfilment of the degree of Masters in Industrial and Organisational Psychology.

Fry, L. W. (2003). Toward a theory of spiritual leadership. The leadership quarterly, 14(6), 693-727. 
Hamidifar, F. (2009). A study of the relationship between leadership styles and employee job satisfaction at Islamic Azad University branches in Tehran, Iran. AU-GSB- e-Journal, 1-13.

Igbaekemen, G. O. (2014). Impact of Leadership Style on Organisation Performance: A Strategic Literature Review. Public Policy and Administration Research, 4(9).

Inyang, B. J. (2004). Management theory: Principles and practices. Merb Publishers. (2nd ed.). Calabar.

Iqbal, N., Anwar, S. \& Haider, N. (2012). Effect of Leadership Style on EP. Arabian Journal of Business and Management Review, 5(5).

Iqbal, N., Anwar, S. \& Haider, N. (2015). Effect of Leadership Style on EP.

Khan, Qureshi Ismail, Rauf, Latif. \& Tachir. (2015). The Styles of Leadership: A Critical Review: Public Policy and Administration, 5(3).

Malik, Z., Saleem, M. \& Ramsha, N. R. (2016). Effect of Leadership Styles on Organizational Citizenship Behaviour in Employees of Telecom Sector in Pakistan. Pakistan Economic and Social Review, 54(2), 385-406.

Mathis, R. L. \& Jackson, J. H. (2009). Human Resource Management. Mason, OH, USA: South-Western Cengage Learning. MCSER Publishing, Rome-Italy, 4(7).

Northouse, P. G. (2004). Leadership Theory and Practice. Pastoral Psychology, 56(4), 403-411.

Obiwuru, T. C., Okwu, A. T., Akpa, V. 0. \& Nwankwere, I. A. (2011). Effects of Leadership Style on Organizational Performance: A Survey of Selected Small Scale Enterprises in Ikosi-Ketu Council Development Area of Lagos State, Nigeria. Australian Journal of Business and Management Research, $1(7)$.

Odumeru, J. A. \& Ifeanyi, G. O. (2013). Transformational vs. transactional leadership theories: Evidence in literature. International Review of Management and Business Research, 2(2), 355-361.

Ojokuku, R. Odetayo, T. \& Sajuyigbe, A. (2012). Impact of Leadership Style on Organizational Performance. American Journal of Business and Management, 1(4), 202-207.

Puni, Ofei1. \& Okoe. (2014). The Effect of Leadership Styles on Firm Performance in Ghana; International Journal of Marketing Studies, 6(1), 1918-719.

PWC. (2012). South African retail and consumer products outlook 2012-2016.

Robbins, S. P., Judge, T. A. \& Sanghi, S. (2007). Organizational Behavior. (12th ed.).

Saasongu, N. (2015). Effects of Leadership Style on Organizational Performance in Small and Medium Scale Enterprises (SMES) in Nigeria. International Journal of Research in Management \& Business Studies, $2(2)$.

Shah, S. M. \& Hamid, K. B. (2015). Transactional Leadership and Job Performance: An Empirical Investigation. Sukkur IBA Journal of Management and Business, 2(10).

Tietjen, M. A. \& Myers, R. M. (1998). Motivation and Job Satisfaction, Management Decision, 36(4), 226-231.

Ukaidi. (2016). The Influence of Leadership Styles on Organizational Performance in Nigeria; Published by European Centre for Research Training and Development UK, 4(4), 25-34. 